\title{
IMPLEMENTATION OF SIJARIEMAS TO REDUCE MATERNAL MORTALITY AT PKU MUHAMMADIYAH, GROBOGAN, CENTRAL JAVA
}

\author{
Firdaus Wahyudi, Arwinda Nugraheni, Diah Rahayu Wulandari, \\ Teddy Wahyu Nugroho, Dea Amarilisa Adespin \\ Department of Public Health, Faculty of Medicine, Diponegoro University
}

\begin{abstract}
Background: Maternal and Neonatal Referal Network Information System (Sistem Informasi Jejaring Rujukan Maternal dan Neonatal, SIJARIEMAS) is a program that seeks to strengthen the referral system of maternal and neonatal health in Indonesia by capitalizing the advancement of information technology. This strategy was developed to reduce maternal mortality rate in Indonesia. This study aimed to analyze the implementation of SIJARIEMAS at PKU Muhammadiyah Hospital in Grobogan District, Central Java.

Subjects and Method: This was a mixed qualitative-quantitative study conducted at PKU Muhammadiyah Gubug Hospital, Grobogan, Central Java, from May to October, 2017. The key informants of the qualitative study included manager and head of hospital ward. The variables under study included Input (Man, Machine, Material, Method), SIJARIEMAS implementation, and Output (maternal mortality).

Results: Standard Operating Procedure already existed with 20 indicators. Machine and Material: Service Room, PC Client/ Tablet, Internet Connection, Speaker, LED Monitor, Phone line, Mobile Phone, already existed. Man: 1 Information Technology technician who was concurrently also an administration personnel, super administration staff, 2 midwives, 1 nurse, 1 general practitioner, and 2 obstetric specialists. Implementation: 10 out of 20 indicators did not performed well. The lowest compliance was that of the referring midwife, who did not communicate well with the Emergency Officers along the way to the Referral Hospital (72.7\%). The most common obstetric problem was premature rupture of membranes (40\%). There was no maternal death of SIJARIEMAS referral during the study.

Conclusion: SIJARIEMAS has been already implemented at PKU Muhammadiyah Gubug Hospital, Grobogan, Central Java. However, its performance has yet to be improved. The implementation should conform with the standard operating procedure.
\end{abstract}

Keywords: SIJARIEMAS, maternal mortality rate

\section{Correspondence:}

Firdaus Wahyudi. Department of Public Health, Facultyof Medicine, Diponegoro University, Jl. Prof. H. Soedarto, SH., Tembalang, Semarang 50275.

Email:drfirdauswahyudi@gmail.com. Mobile: 085641474755.

Mid-International Conference on Public Health, Best Western Premier Hotel, Solo, Indonesia, 18-19 April 2018 | 235 https://doi.org/10.26911/mid.icph.2018.04.15 